\title{
DESIGN AND SIMULATION OF STAND ALONE INTEGRATED RENEWABLE ENERGY SYSTEM FOR REMOTE AREAS
}

\author{
Mokana Mani Susanna ${ }^{1}$, Srinivasa Kishore Teegala ${ }^{2}$, Dattatraya Koushik Surikuchi ${ }^{3}$ \\ ${ }^{I}$ Post Graduate Student, Department of Electrical and Electronics Engineering, GMR Institute of Technology, Rajam- \\ 532127, Andhra Pradesh, India \\ ${ }^{2}$ Assistant Professor, Department of Electrical and Electronics Engineering, GMR Institute of Technology, Rajam- \\ 532127, Andhra Pradesh, India \\ ${ }^{3}$ Assistant Professor, Department of Power Engineering, GMR Institute of Technology, Rajam-532127, Andhra \\ Pradesh, India
}

\begin{abstract}
The availability of energy plays an important role in the development of a country.Electricity availability is essential for economical growth and improvementin quality of life of rural and semi-urban population. In order to achieve this, rural electrification should gain importance. Rural electrification requiresgrid extensionofthe existing power systemto remote areas which is difficult and costly. Impact of burning fossil fuels on environment andrapid depletion increases the supply demand gap. Development of Integrated Renewable Energy System for isolated load is a promisingway outfor rural electrification. Integrated renewable energy systems generate power making use of renewable energy sources that are available regionally which can electrify rural households. In this paper, an attempt has been made to develop an Integrated renewable energy system for power generation using solar and wind resources.Integration of solar and wind systems has been done for supplying isolated load and the model has been implemented in MATLAB/SIMULINK and the results are summarized.
\end{abstract}

Keywords- Renewable Sources, Solar System, Wind System, Integrated Renewable Energy System, Power.

\section{INTRODUCTION}

For the development of a country, electrification of rural areas also plays a key role as it improves living standards, education, better transportation system, communication system, health care and provides economic stability. In order to accomplish this we need to extend the grids of the existing power system to remote areas which is difficult and costly. The dearth of conventional energy resources, increase in fuel prices and concern on the environment from the impacts of burning fossil fuels has made power generation from conventional energy sources unsustainable. The demand and supply gap continues to increase exponentially if not met by other resources of power generation. Integrated renewable energy system (IRES) provides the most promising solution for rural electrification of isolated areas devoid of power grid access [1]. The current international development in rural electrification is to exploit renewable energy resources to the maximum extent.

Renewable Energy (RE) is in-exhaustive while other sources of energy are limited and are prone to depletion. The environmental impact of power generation from renewable energy technologies is less as compared to conventional energy technologies as these are clean sources of energy [2]. The only drawback of opting for power generation from a renewable energy source is its availability. Due to the heavy dependence of these sources on climatic conditions and natural uncontrollability, electrical power can be generated only when they are accessible. In this regard, taking into account a particular renewable energy source for power generation is associated with the problem of reliability of supply [3]. Integrating two or more renewable energy sources is an impressive solution to provide uninterrupted power supply and accomplish the demand of electricity. The rapid advancement in photovoltaic and wind turbine generator technologies provide vast opportunities for utilizing solar and wind resources for electrical power generation.

In this paper, a stand-alone IRES model employing solar and wind power generation systems is presented. The solar cell designed is using the static equations of a PV cell. The solar system consisting of three panels connected in series is designed [4]. The Variable Speed Wind Energy Conversion System consisting of Horizontal Axis Wind Turbine connected to Permanent Magnet Synchronous Generator (PMSM) is designed [5]. The wind system presented is direct driven system. Both the sources are connected to a common DC bus, thus integrating both the sources. This implemented system is Integrated Renewable Energy System. This system is a two stage conversion system. Initial stage consisting of generation and boosting the voltage levels to the required level and the second stage is the conversion of DC voltage to the $\mathrm{AC}$, to interface the load to the system [3]. The Boosting of the DC voltage can be obtained using DC-DC converter i.e. Boost or Step-up converter and the inversion of DC to AC can be achieved using an inverter. To reduced the EMI and the harmonics in the system, Pulse Width Modulation (PWM) technique and LC filter are employed. 


\section{MODELLING OF SOLAR SYSTEM}

In this system, power generation is done by converting the available solar radiation into electrical energy using a photovoltaic (PV) cell. The solar radiation is electromagnetic and it can be directly converted into electricity through photo voltaic effect. A single photovoltaic cell can produce a very small amount of electrical energy. In order to rise the power level to that which is convenient for use, these cells must be connected in series and parallel. The series and parallel connection of the $\mathrm{PV}$ cell is known as a module and modules connected in series and parallel is called array as shown in Fig. 1. These series and parallel connections of PV cells aid in obtaining increased voltage and increased current [4].

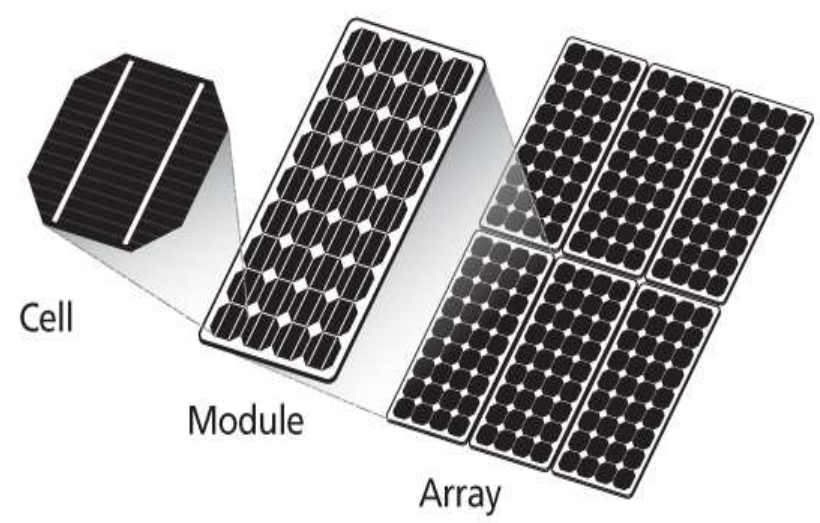

Fig-1: Solar PV Panel

The solar PV system is implemented in MATLAB/SIMULINK by using the V-I characteristic equations of PV cell. The corresponding circuit of the generic PV model consists of a photo current, diode, a resistor in parallel corresponding to leakage current and a resistor in series corresponding to internal resistance to current flow as shown in Fig.2[6, 7].

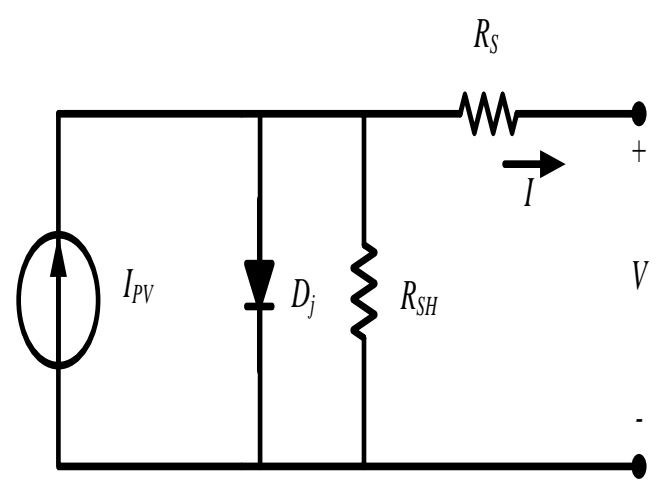

Fig-2: Generic model of PV cell

Current equation is given as

$I=I_{p v}-I_{0}\left[e^{\left(\frac{V+I R_{s}}{a V_{T}}\right)}-1\right]-\frac{V+I R_{s}}{R_{s h}}$
Where,

$V_{T}=\frac{N_{s} K_{T}}{q}$

$I_{p v}=$ Light generated current or photo current and is given as

$I_{p v}=\frac{a}{a_{n}}\left[I_{p v n}+K_{1}\left(T-T_{n}\right)\right]$

$I_{o}=$ Diode current

$q=1.6 * 10^{-19} c=$ charge of electron

$K=1.38 * 10^{-23} \mathrm{~J} / K=$ Boltzmann's constant

$R_{s}=$ series resistance

$\mathrm{a}=$ diode ideality constant

$R_{\text {sh }}=$ shunt resistance

$\mathrm{T}=$ operating temperature

$\mathrm{I}_{\mathrm{pvn}}$ represents the short circuit current of the cell at $25^{\circ} \mathrm{C}$ and $1 \mathrm{Kw} / \mathrm{m}^{2}, \mathrm{~K}_{1}$ represents the cell's short circuit current temperature coefficient, $T_{n}$ is considered as reference temperature, $G_{n}$ represents the nominal irradiance and $G / G_{n}$ is solar insolation in $\mathrm{Kw} / \mathrm{m}^{2}$ radiation [8]. $\mathrm{I}_{0}$ the saturation current of the cell is given by the Eq. (2),

$I_{0}=I_{o n}\left[\frac{T}{T_{n}}\right]^{3} e^{\left(\frac{q E_{g}\left(\frac{1}{T_{n}}-\frac{1}{T}\right)}{a K}\right)}$

$\mathrm{I}_{\text {on }}$ represents the reverse saturation current of the cell at a particular reference temperature and solar radiation. $\mathrm{E}_{\mathrm{g}}$ is energy band gap of semiconductor used in the PV cell. Band gap of silicon at $25^{\circ} \mathrm{C}$ is 1.12 .

$$
I_{0 n}=\frac{I_{s c n}}{e^{\left(\frac{V_{0 c n}}{a V_{T n}}\right)}-1}
$$

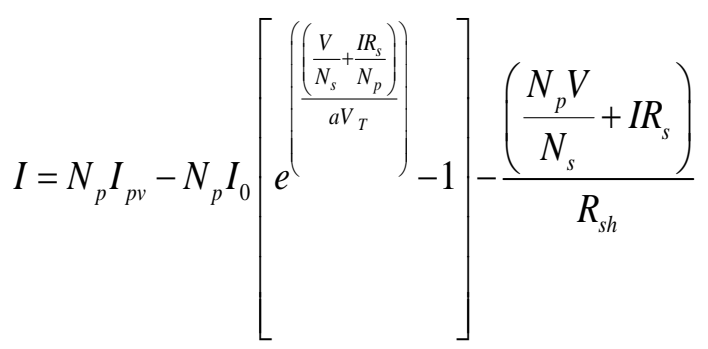

The equivalent circuit of general PV array is as shown in Fig. 3. 


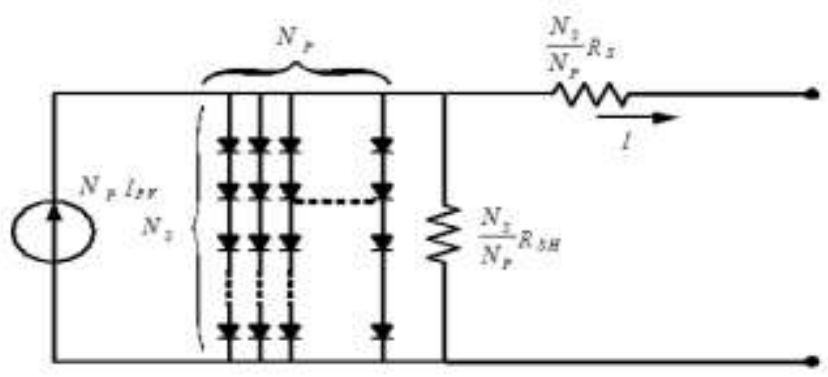

Fig-3: Equivalent circuit of a general PV array.

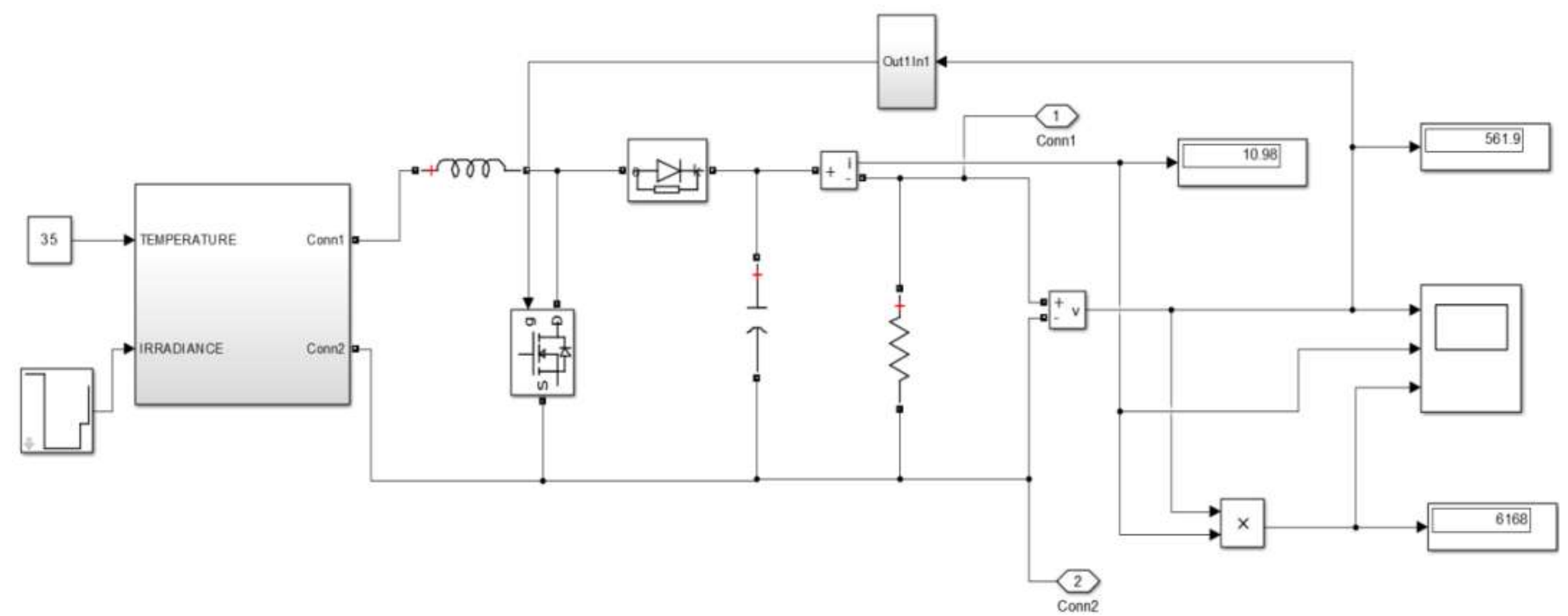

Fig-4: MATLAB/Simulink model of Solar power generation.

\section{MODELLING OF WIND SYSTEM}

Wind energy is the one of the finest technologies existing now a days to provide a sustainable energy supply. Wind energy system is one of the emergent source of renewable power generation with negligible adverse environmental impacts and is considered as one of the impending sources of alternative energy for the future. As compared to large scale, small scale wind energy conversion systems are more efficient and cost effective. Standalone wind energy conversion systems offer a feasible solution to generate power at isolated localities where utility grid extension is not feasible. The surface of earth heats and cools disproportionately, creating atmospheric stress zones that result in flow of air from high pressure areas to low pressure areas which causes wind. Wind is also created by rotary motion of earth. This wind is able to exert a force and creates movement which is utilized in the wind energy conversion systems. The power present in the wind in the form of kinetic energy is converted into electrical power. This conversion is known as wind energy conversion system(WECS). The kinetic energy is captured by the turbine blades of wind turbine and it is converted into load torque. This shaft is directly connected to the generator rotor shaft. This connection is known as direct driven system. The power available in the wind is given by the Eq. (5).
Modelling of PV array based solar power generation was implemented in MATLAB/Simulink and the proposed model is simulated. A low magnitude DC power is generated which is incompatible for supplying loads. In order to step up the output voltage obtained by the PV array, a boost converter is used. The MATLAB/Simulink model of solar power generating system employing PV modules along with boost converter is as shown in Fig. 4. 
Where $\mathrm{w}$ is the rotational speed, $\mathrm{R}$ is radius of tip rotor and $\mathrm{v}$ is wind speed $\left(\mathrm{ms}^{-1}\right)$. Power coefficient $\mathrm{C}_{\mathrm{p}}$ and tipspeed ratio $\lambda$ are used to describe the performance of wind turbine rotor. The present work represents a system in which a PMSG feeds an isolated load through boost converter in a closed loop configuration. Fig. 5 shows a wind turbine connected to PMSG to generate electrical energy [9]. The conversion is in the form of KE-ME-EE. Due to deviations in wind, the corresponding electrical energy output is also fluctuating. The AC output voltage of PMSG is converted into DC voltage by using diode rectifier and rectifier filters are used in order to filter the DC voltage [10, 11].

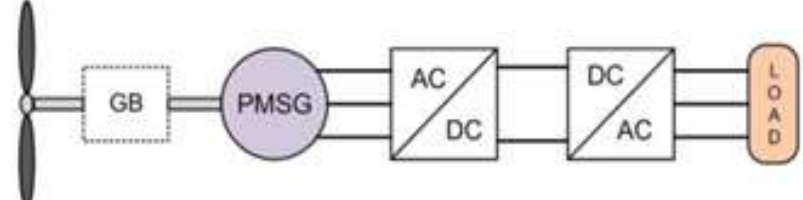

Fig-5: Variable-speed wind turbine with PMSG.

\subsection{Modelling of PMSG}

The permanent magnet synchronous generator is used to generate the electricity from the mechanical energy. The dynamic model of the PMSG is derived from two-phase synchronous reference frame in which the $\mathrm{q}$ axis is $90^{\circ}$ ahead $\mathrm{q}$ the $\mathrm{d}$ axis with respect to direction $\mathrm{q}$ rotation as shown in Fig. 6. [12].

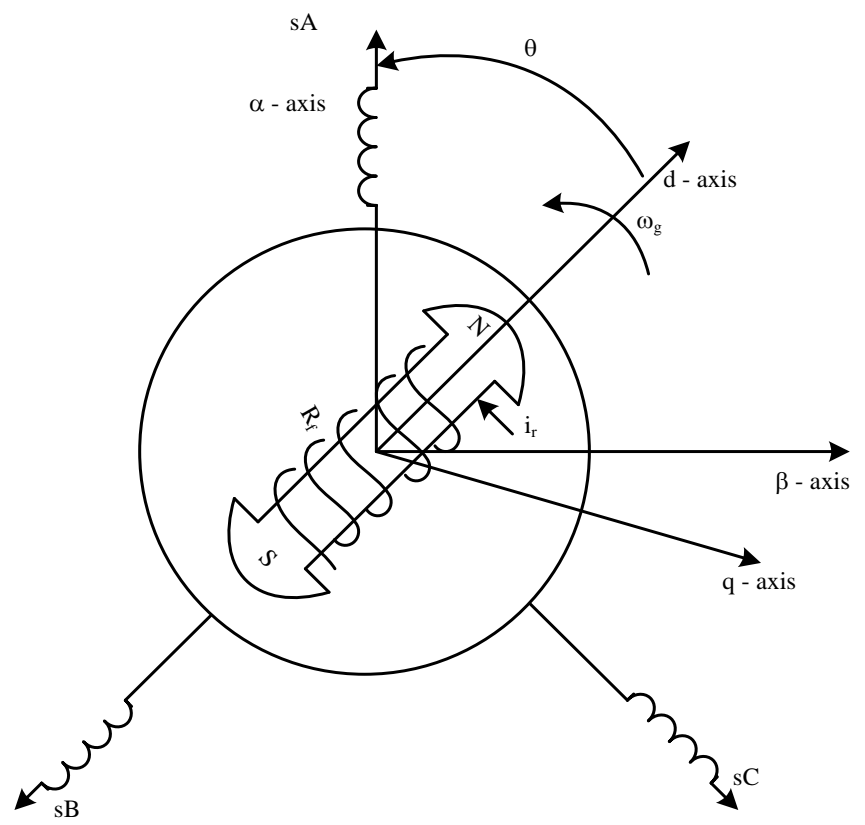

Fig-6: $d-q$ and $\alpha-\beta$ axis of a typical salient-pole synchronous machine.

The mechanical angle is the angle between the d-axis of the rotor and d-axis of the stator. The assumptions made for mathematical modelling of PMSG are: (a) the mechanical sitting of the stator winding is $120^{\circ}$ apart in the air. The magnetic, hysteresis and saturation effects are negligible. The rotor inductance has negligible effect on it due to the presence of stator slots, when damping windings are not taken into considerations. Hence, the Stator construction is in symmetrical manner. (b) The other assumption made is the neglecting the winding capacitances with constant resistances, which makes power losses constant [13].

The mathematical model of PMSG in synchronous reference frame is given by

$$
\begin{aligned}
& \frac{d i_{a}}{d t}=\frac{1}{L_{d s}} v_{d}-\frac{r_{s}}{L_{d s}} i_{d}+\frac{L_{q s}}{L_{d s}} \omega_{e} i_{q} \\
& \frac{d i_{q}}{d t}=\frac{1}{L_{q s}} v_{q}-\frac{r_{s}}{L_{q s}} i_{q}-\frac{L_{d s}}{L_{q s}} \omega_{e} i_{d}-\frac{\psi_{f} \omega_{e}}{L_{q s}}
\end{aligned}
$$

Where,

$\frac{v_{d}}{i_{d}} \mathrm{~d}$-axis voltage $(\mathrm{V}) /$ current(A)

$\frac{v_{q}}{i_{q}}$ q-axis voltage $(\mathrm{V}) / \operatorname{current}(\mathrm{A})$

$r_{s}$ stator resistance $(\Omega)$

$L_{d s}$ stator d-axis inductance $(\mathrm{H})$

$L_{q s}$ stator q- axis inductance $(\mathrm{H})$

$\psi_{f}$ permanent magnetic flux $\left(\mathrm{W}_{\mathrm{b}}\right)$

$\omega_{e}$ electrical speed $(\mathrm{rad} / \mathrm{s})$

$\omega_{e}=p \omega_{m}$

Where,

$p$ pole pairs

$\omega_{m}$ mechanical speed $(\mathrm{rad} / \mathrm{s})$

$T_{e}=1.5 p\left(L_{d s}-L_{q s}\right) \mathrm{i}_{d} i_{q}+i_{q} \psi_{f}$

$\frac{d \omega_{m}}{d t}=\frac{1}{J}\left(T_{e}-F \omega_{m}-T_{m}\right)$

Where,

$J$ combined inertia of load and rotor $\left(\mathrm{kg}-\mathrm{m}^{2}\right)$

$F$ combined viscous friction of load and rotor(Nm-s)

$T_{m}$ shaft mechanical torque (N-m)

The equivalent circuit of PMSG in $\mathrm{d}-\mathrm{q}$ synchronous rotating reference frame as shown in Fig. 7 and Fig. 8. 


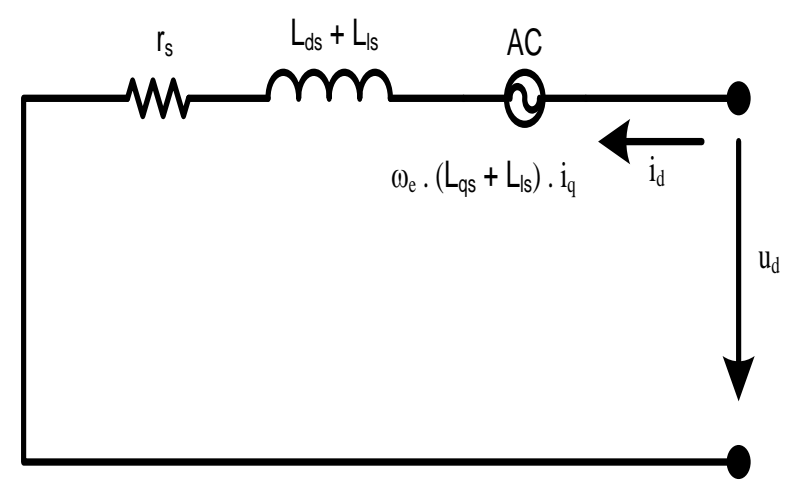

Fig-7: d-axis equivalent circuit

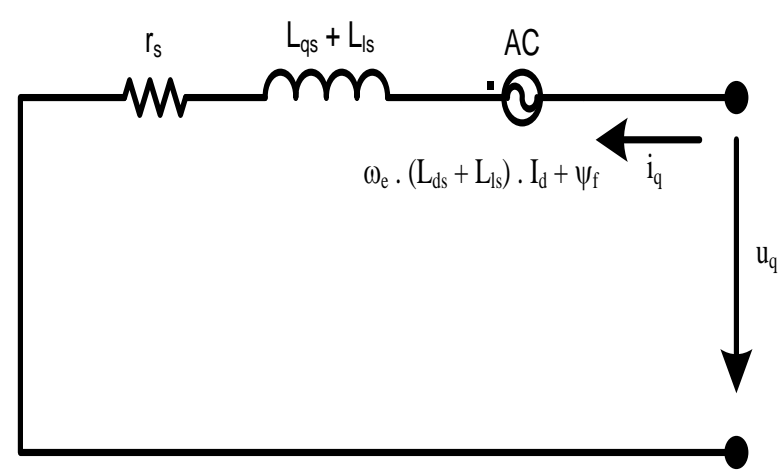

Fig-8:q-axis equivalent circuit

A wind power generating system along with boost converter is designed in matlab and it is as shown in Fig. 9 its simulation results are as shown in Fig. 14 and Fig. 15.

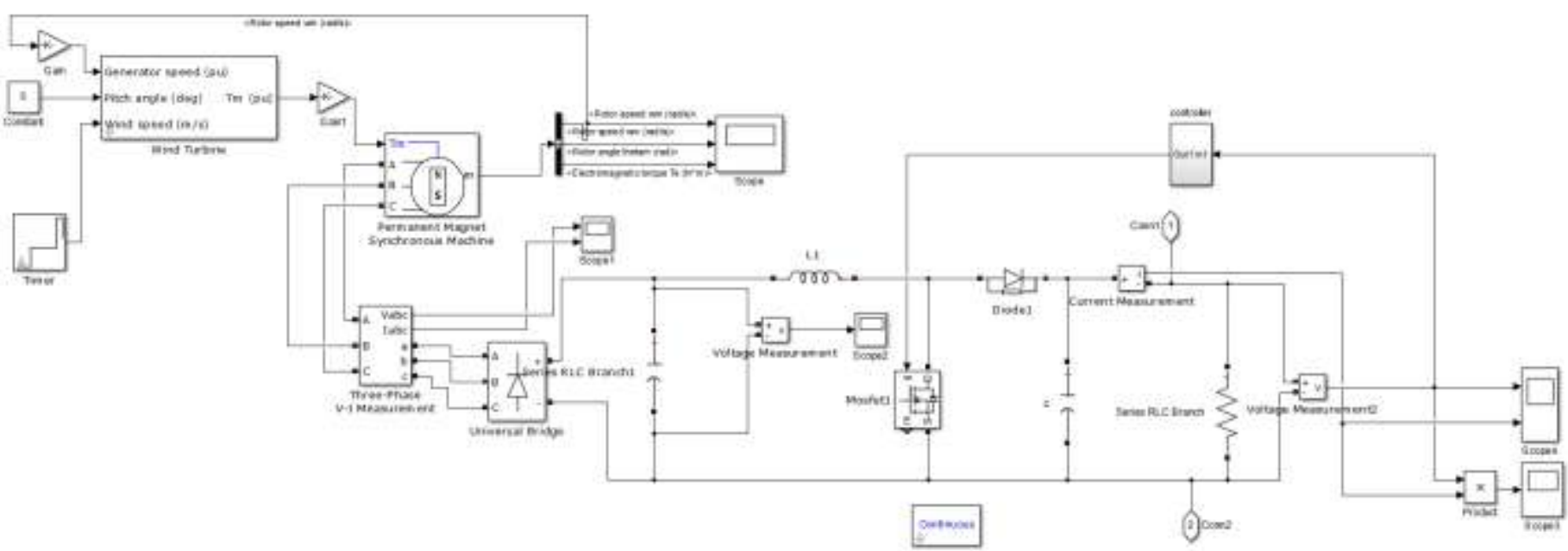

Fig-9: wind power generating system

\section{INTEGRATED RENEWABLE ENERGY}

\section{SYSTEM}

Integrated renewable energy system utilizes two or more locally available renewable energy resources like hydro, solar, wind, biomass, geothermal etc., to supply the electricity in local villages [14]. By integrating renewable energy sources which are available in that area we can generate and distribute power at low cost and fulfil the demand of electricity in remote and rural households. The solar and wind power generating systems are integrated. The block diagram of this system is as shown in Fig. 10.

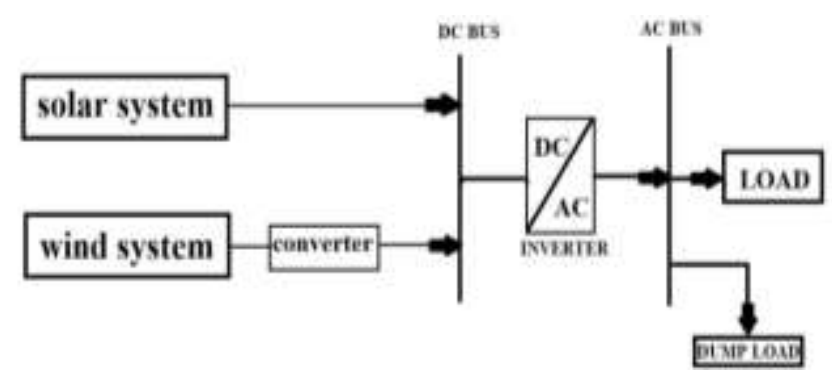

Fig-10: Block diagram of Integrated solar and wind power systems.
This is a simple block diagram representation of IRES with two renewable energy systems. Here solar system (RES1) is connected to DC bus as the output of the solar power system is DC power. If the power output is AC as wind system then it is given to DC bus through converter. By using the inverter we convert the DC power to AC and then it is supplied to load [15]. If the supply is more than load then the excess power then it is supplied to dump loads [16]. The renewable energy sources are of low cost and by using them we can overcome the scarcity of conventional fuels. Rural energy needs can be satisfied [17]. They are inexhaustible and environment friendly. We can have a improved public health and environmental quality. The IRES is one of the best solution to electrify the un-electrified areas. solar system and wind system are integrated to supply a load of 3000 watts is designed in matlab and it is as shown in Fig. 11 and its output voltage, line voltage, current and power are shown in Fig. 16, Fig. 17 and Fig. 18 respectively . 


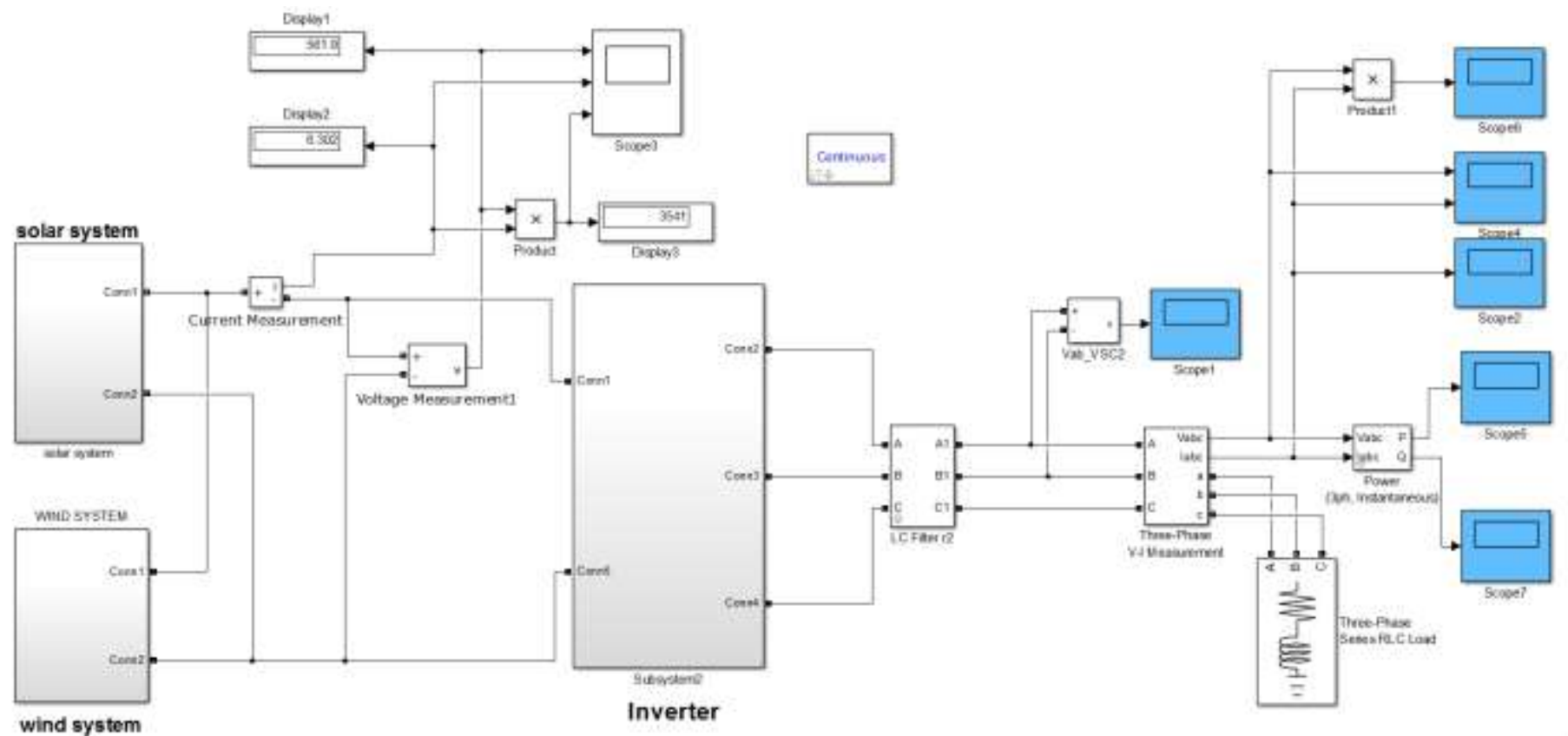

Fig-11: solar and wind integrated system with non-linear load.

\section{SIMULATION RESULTS AND VALIDATION}

The solar panel is designed for an open circuit voltage $\left(v_{o c}\right)$ of $36.88 \mathrm{v}$ and short circuit current $\left(I_{s c}\right)$ of $8.72 \mathrm{~A}$. The complete system consisting of three solar panels gives the open circuit voltage $(v)$ and short circuit current $(I)$ are $200 \mathrm{v}$ and $8.251 \mathrm{~A}$. The three phase, when connected to power system, the load requirements are nominal voltage of $440 \mathrm{~V}$ with $50 \mathrm{~Hz}$ frequency. The requirements of the load, in this case, can be met by either converting the DC to AC supply and stepping up the voltage using a step-up transformer or by using boost converter. Using a transformer requires special equipment and space for maintenance and operation. A boost converter is used with a gain value of 3.5 and the voltage $(v)$ increased to 700 volts thereby the current ( $I$ ) value is 2.2 amps.

The boost converter is a step-up DC/DC converter. The converter uses a transistor switch, typically a MOSFET or IGBT. Depending on the switching pulses and formula, the boosted voltage $\left(v_{o}\right)$ can be seen as $v_{i}\left(\frac{1}{1-D}\right)$ which gives the relation between $v_{i}$ and $v_{o}$. The gain value of the boost converter is the inverse of the duty cycle i.e., $G=1 / D$. And duty cycle is defined as the ratio of switch on time period of switch to total time period of switch. Hence the output voltage and current of boost converter obtained for a duty cycle of 0.75 is $700 \mathrm{~V}$ and $2.2 \mathrm{~A}$ for an input of $200 \mathrm{~V}$ and $8.251 \mathrm{~A}$. Hence the efficiency of this boost converter is $98 \%$.
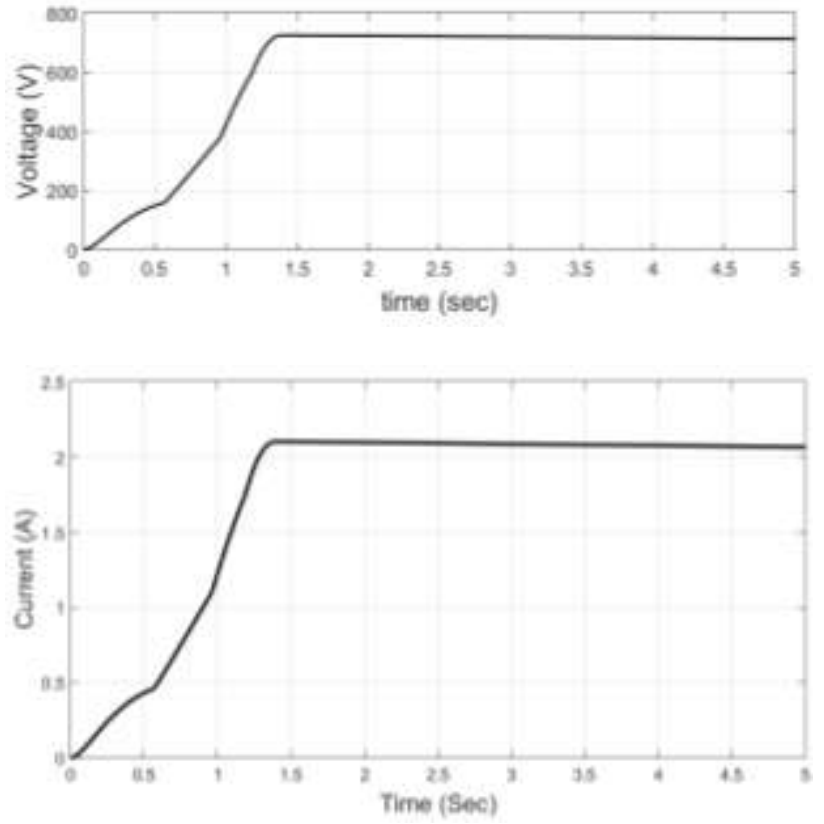

Fig-12: Solar system output voltage and current.

The solar system is simulated and the required voltage of $700 \mathrm{~V}$ and current of 2.2A are obtained as shown in Fig. 12.

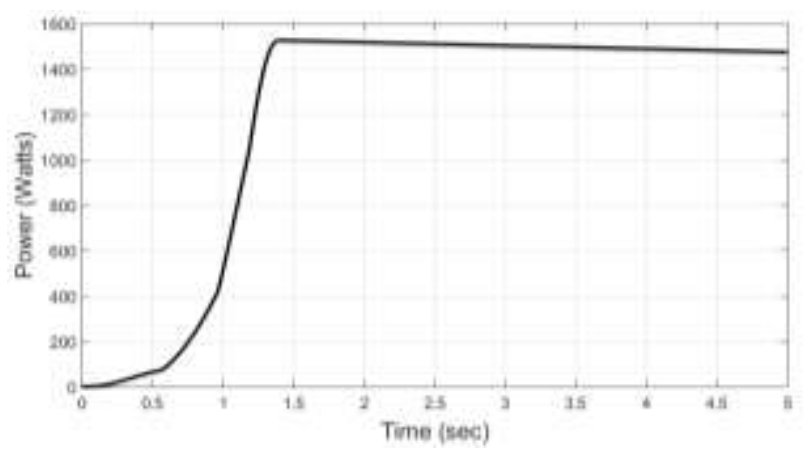

Fig-13: Solar system output power 
The required output power of $1500 \mathrm{~W}$ from the solar system is obtained and the simulation result is as shown in Fig. 13.

A variable speed wind energy conversion system consists of a PMSM with wind turbine. The output obtained from wind turbine connected to PMSM is variable with respect to its magnitude and frequency. So as to attain constant output, the AC output of wind energy is converted into DC. This DC is maintained at a required DC level using boost. The output of boost is interconnected to the solar DC system. The solar DC system is maintained at $700 \mathrm{~V}$ constant DC. Hence, the boost converter of wind has to maintain a DC link voltage of $700 \mathrm{~V}$. This interlink of DC voltages from both the renewable sources forms the integrated renewable energy source. Hence the efficiency of this boost converter is $97 \%$.
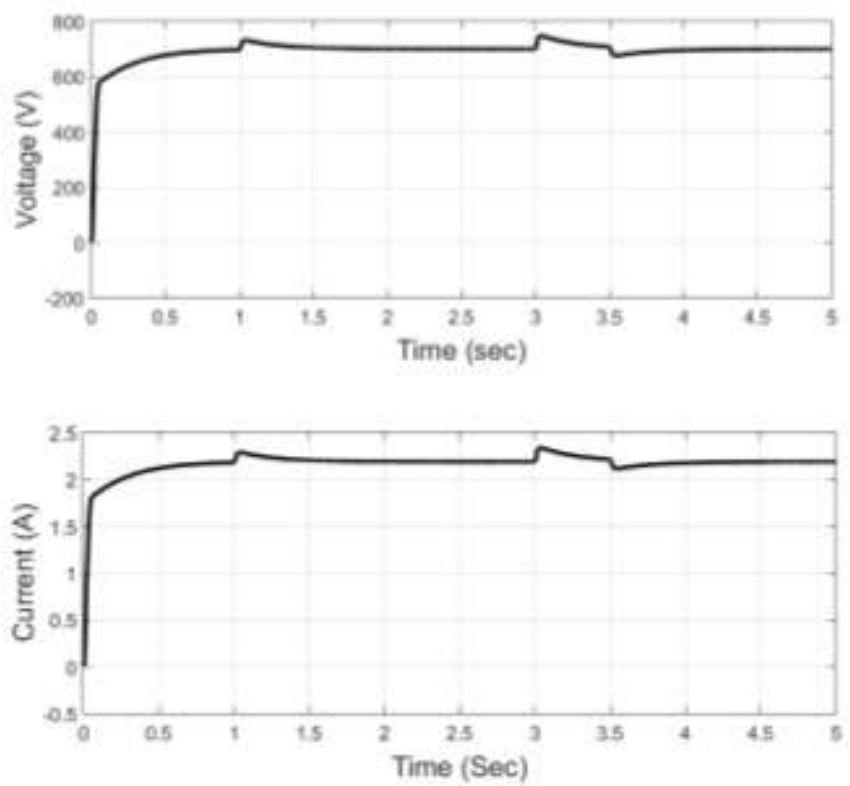

Fig-14: Wind system output voltage and current.

The wind system is simulated and the required voltage of $700 \mathrm{~V}$ and current of 2.2A are obtained as shown in Fig. 14.

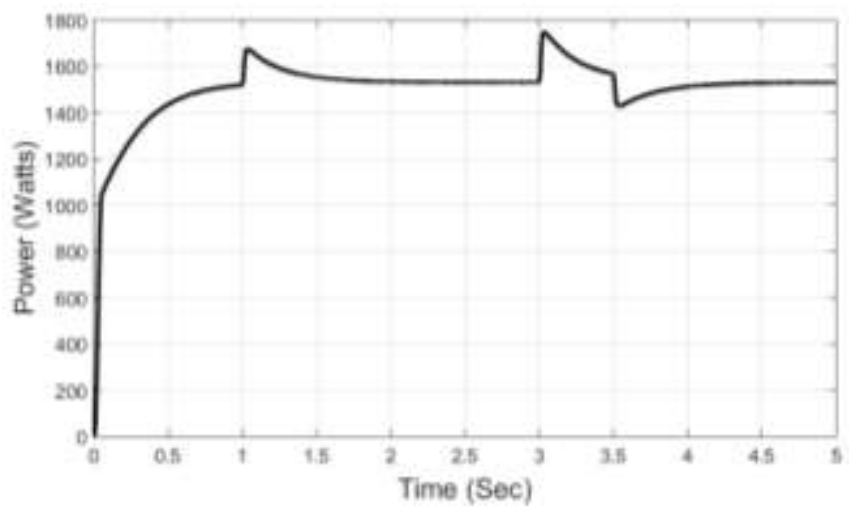

Fig-15: Wind system power output

The required output power of $1500 \mathrm{~W}$ from the wind system is obtained and the simulation result is as shown in Fig. 15. The solar system and wind system having parametric values of $1500 \mathrm{~W}, 700 \mathrm{~V}$ and $2.2 \mathrm{~A}$ are integrated to get the desired output power of $3000 \mathrm{~W}$. The designed load is an AC three phase load with requirements of $440 \mathrm{~V}$ and $50 \mathrm{~Hz}$ system. To integrate the load with the system, an inverter is used as interface between the load and the system. It also converts DC source to AC. Thereby the obtained output voltage $(v)$ and current (I ) from inverter are $440 \mathrm{~V}$ and $6.9 \mathrm{~A}$ respectively.

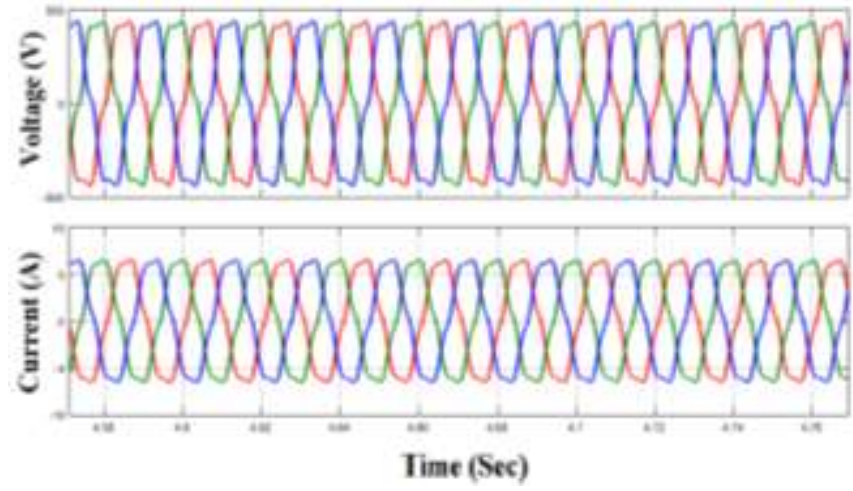

Fig-16: Integrated solar and wind system output voltage and current.

The Integrated solar and wind system is simulated and the required voltage of $440 \mathrm{~V}$ and current of $6.9 \mathrm{~A}$ are obtained as shown in Fig. 16.

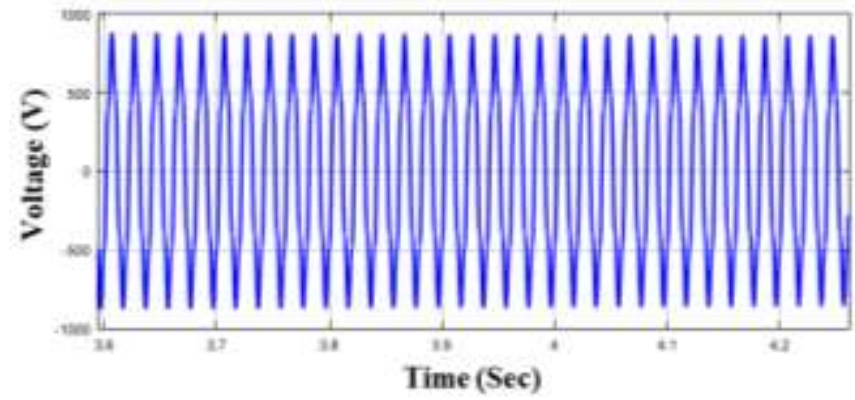

Fig-17: Integrated solar and wind system line voltage

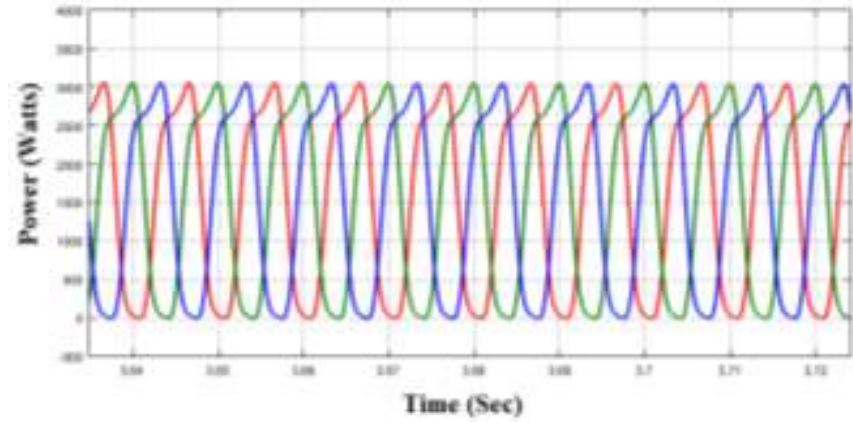

Fig-18: Integrated solar and wind system power output.

Hence the required output power of $3000 \mathrm{~W}$ from the integrated solar and wind system is obtained and the simulation result is as shown in Fig. 18.

\section{CONCLUSION}

Uneconomical extension of the grid has led to the generation of electric power at the user end. Integrated renewable energy systems have been recognized as a feasible option for energy supply in stand-alone applications and it is also cost effective. With developed technologies the use of 
renewable energy sources such as micro-hydro, wind, solar, biomass and biogas is being explored. IRES electrifies the remote areas using renewable energy sources available in that area. In this paper solar and wind energies are considered and integrated. This paper provides design of solar and wind system and integrated solar and wind system for an isolated load of 3000watts. The simulation results of solar system and wind system with parametric values of $1500 \mathrm{~W}, 700 \mathrm{~V}$ and $2.2 \mathrm{~A}$ and integrated solar and wind system for isolated load of $3000 \mathrm{~W}$ with three phase AC voltage and current of $440 \mathrm{~V}$ and 6.9A respectively are shown. By using IRES for isolated loads the social and economic status of people will be improved.

\section{REFERENCES}

[1]. L. A. De Souza Ribeiro, O. R. Saavedra, S. L. De Lima, and J. G. De Matos, "Isolated micro-grids with renewable hybrid generation: The case of Lencois island", IEEE Trans. Sustain. Energy, vol. 2, no. 1, pp. 1-11, 2011.

[2]. J. C. Mourmouris, C. Potolias, and J. G. Fantidis, "Evaluation of Renewable Energy Sources Exploitation at Remote Regions , using Computing Model and MultiCriteria Analysis : A Case-Study in Samothrace , Greece", Int. J. Renew. ENERGY Res., vol. 2, no. 2, pp. 308-316, 2012.

[3]. K. P. Reddy and M. V. G. Rao, "Modelling and Simulation of Hybrid Wind Solar Energy System using MPPT”, Indian J. Sci. Technol., vol. 8(23), no. September, pp. 4-8, 2015.

[4]. B. K. Das and D. Bisht, "MATLAB / SIMELECTRONICS Models Based Study of Solar Cells", Int. J. Renew. ENERGY Res., vol. 3, no. 1, pp. 1-5, 2013.

[5]. M. Izadbakhsh, A. Rezvani, M. Gandomkar, and S. Mirsaeidi, "Dynamic Analysis of PMSG Wind Turbine under Variable Wind Speeds and Load Conditions in the Grid Connected Mode", Indian J. Sci. Technol., vol. 8(14), no. July, pp. 1-7, 2015.

[6]. H. Tsai, C. Tu, and Y. Su, "Development of Generalized Photovoltaic Model Using MATLAB / SIMULINK", Proc. World Congr. Eng. Comput. Sci. 2008 WCECS 2008, Oct. 22 - 24, 2008, San Fr. USA, p. 6, 2008.

[7]. M. G. Villalva, J. R. Gazoli, and E. R. Filho, "Comprehensive Approach to Modeling and Simulation of Photovoltaic Arrays", Power Electron. IEEE Trans., vol. 24, no. 5, pp. 1198-1208, 2009.

[8]. Y. Kuo, W. Tung, and L. Liu, "Smart Integrated Circuit and System Design for Renewable Energy Harvesters", IEEE J. Photolvoltaics, vol. 3, no. 1, pp. 401-406, 2013.

[9]. Y. Errami, M. Ouassaid, and M. Maaroufi, "Control of a PMSG based wind energy generation system for power maximization and grid fault conditions", in Energy Procedia, vol. 42. Elsevier, pp. 220-229, 2013.

[10]. A. Mirecki, X. Roboam, and F. Richardeau, "Architecture complexity and energy efficiency of small wind turbines", Ieee Trans. Ind. Electron., vol. 54, no. 1, pp. 660-670, 2007.

[11]. A. Urtasun, P. Sanchis, I. San Martin, J. Lopez, and L. Marroyo, "Modeling of small wind turbines based on PMSG with diode bridge for sensorless maximum power tracking", Renew. Energy, vol. 55. Elsevier, pp. 138-149, 2013.

[12]. P. Udhayakumar, C. Saravanan, and M. Lydia, "Stand - Alone Wind Energy Supply System Using Permanent
Magnet Synchronous Generator", Int. J. Innov. Technol. Explor. Eng., vol. 2, no. 3, pp. 130-135, 2013.

[13]. B. M. Amine, M. Ahmed, A. Tayeb, and Z. souhila, "Modelling and control of standalone wind energy conversion system", Int. J. Adv. Eng. Technol. Jan. 2014., vol. 6, no. 6, pp. 2382-2390, 2014.

[14]. A. Chauhan and R. P. Saini, "A review on Integrated Renewable Energy System based power generation for stand-alone applications: Configurations, storage options, sizing methodologies and control", Renewable and Sustainable Energy Reviews, vol. 38. Elsevier, pp. 99-120, 2014.

[15]. R. W. Wies, R. a. Johnson, A. N. Agarwal, and T. J. Chubb, "Economic analysis and environmental impacts of a PV with diesel-battery system for remote villages", IEEE Power Eng. Soc. Gen. Meet. 2004., vol. 20, no. 2, pp. 692 700, 2004.

[16]. C. Wang and M. H. Nehrir, "Power management of a stand-alone wind/photovoltaic/fuel cell energy system", IEEE Trans. Energy Convers., vol. 23, no. 3, pp. 957-967, 2008.

[17]. A. Chauhan and R. P. Saini, "Techno-economic feasibility study on Integrated Renewable Energy System for an isolated community of India", Renewable and Sustainable Energy Reviews, vol. 59. Elsevier, pp. 388-405, 2016.

\section{BIOGRAPHIES}

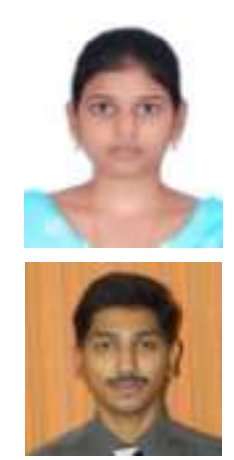

Miss. M.Mani Susanna was born in India. She received her B.Tech degree in Electrical and Electronics Engineering in 2014 and pursuing M.Tech in Power and Industrial Drives in GMRIT, Rajam, India. University, Hyderabed, India in 2003 and 2006 respectively. $\mathrm{He}$ received his Ph.D. degree in the area of Power Transmission Lines from Alternate Hydro Energy Centre, IIT Roorkee, India. He served the industry as Junior Engineer (Electrical) during 2003-04. Since 2006, he is serving as Assistant Professor in the Department of Electrical and Electronics Engineering, GMR Institute of Technology, Rajam, Andhra Pradesh, India. He is a member of ISTE, India and IAENG, Hongkong. His main research interests are power transmission, renewable energy, environmental issues and cost analysis.

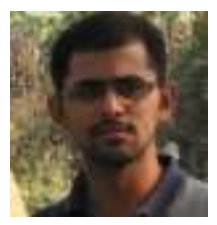

Mr. S Dattatraya Koushikwas born in India. He received his B.Tech degree in Electrical and Electronic Engineering from JNTU and M.tech in Power Eletronics from VIT University, India. Presently, he is serving as Assistant Professor in the Department of Power Engineering, GMR Institute of Technology, Rajam, Andhra Pradesh, India.His main research interests are power electronics and renewable energy. 